\title{
Helminth communities of the exotic introduced turtle, Trachemys scripta elegans in southwestern Spain: Transmission from native turtles
}

\author{
J. Hidalgo-Vila ${ }^{\mathrm{a}, *}$, C. Díaz-Paniagua ${ }^{\mathrm{a}}$, A. Ribas ${ }^{\mathrm{b}}$, M. Florencio ${ }^{\mathrm{a}}$, N. Pérez-Santigosa ${ }^{\mathrm{a}}$, J.C. Casanova ${ }^{\mathrm{b}}$

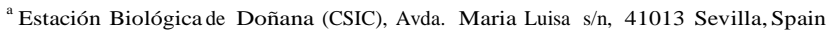 \\ ${ }^{\mathrm{b}}$ Laboratory of Parasitology, Faculty of Pharmacy, University of Barcelona, Avda. Diagonal s/n, 08028 Barcelona, Spain
}

Keywords:

Cross transmission

Exotic turtles

Helminth communities

Native turtles

\begin{abstract}
We report the prevalence and diversity of helminth parasites found in native turtles Mauremys leprosa and Emys orbicularis from three localities in southwestern Spain and we describe the helminth communities of exotic turtles Trachemys scripta elegans coexisting in the wild with both native turtle species. Five nematodes species were identified, of which Serpinema microcephalus was the only species common between two localities, although infection parameters were different between them. This is the first report of cross transmission of S. microcephalus and Falcaustra donanaensis from native to exotic turtles and the first report of genus Physaloptera in turtles of the Palearctic Region. Continuous releasing of exotic pet turtles in wildlife ecosystems increases the risk of parasite introductions and, consequently, potential transmission to native species, and highlights the impending need for regulation of pet turtle trade in Europe.
\end{abstract}

\section{Introduction}

The red-eared slider turtle, Trachemys scripta elegans, is an invasive species massively traded worldwide as a pet (Salzberg, 1995; Telecky, 2001). In Spain there are two native aquatic turtles, the Mediterranean pond turtle (Mauremys leprosa) and the European pond turtle (Emys orbicularis), which are presently threatened by habitat degradation or fragmentation as well as by the introduction of exotic turtles (Pleguezuelos, 2002; Cox et al., 2006). Competition with the introduced species T. s. elegans has been demonstrated to affect survival of E. orbicularis (Cadi and Joly, 2003, 2004). Additionally, the presence of these exotic turtles could also increase the risk of introduction of exotic microorganisms and diseases to the native fauna.

In this study, we report the helminth parasites found in wild populations of native turtles M. leprosa and E. orbicularis as well as the helminth communities of exotic turtles T. s. elegans in coexistence with the native ones, with the aim of assessing whether exotic turtles host helminths alien to native hosts and to determine the risk of transmission to native turtles.

\section{Materials and methods}

During 2002 and 2003 we analysed the presence of helminth parasites in exotic and native turtles from three localities in south-

\footnotetext{
* Corresponding author. Tel.: +44 207449 6489; fax: +44 2074832237. E-mail address: judit@ebd.csic.es (J. H.-Vila).
}

western Spain: (a) Doñana Biological Reserve (Doñana), a natural reserve in which there are no exotic turtles; (b) Acebuche Lagoon (Acebuche) and, (c) Portil Lagoon (Portil). Exotic and native turtles are known to coexist in Acebuche and Portil sites.

Because this study was conducted within the framework of a program for the eradication of exotic turtles, different methods were used for the collection of parasites from native and exotic individuals. Fifty nine exotic turtles (T. s. elegans) were captured and humanely sacrificed using Thiopental sodium injection (Tiobarbital, Braun Medical). Turtles' digestive tracts were removed, dissected and placed in Ringer's solution for microscopical examination. The digestive tracts of seven M. leprosa and three E. orbicularis found dead in poaching' traps were too analysed following the same procedure.

Additionally, faecal samples of 96 live native turtle's individuals (57 M. leprosa and 39 E. orbicularis) were directly analysed for the presence of parasites using a binocular magnifying glass.

Helminths were counted, isolated and preserved in $70 \%$ ethanol and temporarily fixed with Amann lactophenol for identification. Species were identified according to Baker (1979, 1980), Hidalgo-Vila et al. (2006) as described previously.

The use of descriptive ecological terms follows: Bush et al. (1997). Prevalence, intensity of infection, abundance of each helminth species and abundance and richness of parasites from each locality were determined for adult (T. s. elegans) from Acebuche and Portil, where sample sizes were large and the total number of parasites could be established by the examination of digestive tracts. For M. Leprosa and E. orbicularis, only the prevalence of infection was estimated, due to low sample sizes. 
Differences in prevalence of infections were evaluated by comparing the number of animals infected in both localities using $\mathrm{v}^{2}$ test. Non parametric Kruskal-Wallis tests were used for comparisons of intensity of infections and abundance of parasites (Serpinema microcephalus) between populations and for comparisons of species richness and abundance of helminths between populations. Differences were considered significant when the p-value was $<0.05$. Parasite diversity was calculated using Brillouin's index (Magurran, 2004).

\section{Results}

Five nematodes species were found in the studied species. S. microcephalus, (Dujardin, 1845) (Camallanidae), Falcaustra donanaensis, (Hidalgo-Vila et al., 2006) (Kathlaniidae), Falcaustra sp. (Lane, 1915) (Kathlaniidae), Aplectana sp. (Railliet and Henry, 1916) (Cosmocercidae) and Physaloptera sp. (Rudolphi, 1819) (Physalopteridae). With the exception of Aplectana sp., all nematodes were common to native and exotic turtles (Tables 1 and 2).

We found helminths in all the intestinal tracts of the native turtles analysed (Table 1). In contrast, fewer parasites were detected in the faeces, representing low infection prevalence's, 28.7\% (16/ $57)$ in M. leprosa and $12.8 \%$ (5/39) in E. orbicularis. However, faecal examination revealed two more helminth species, with Falcaustra sp. found in one E. orbicularis from Doñana and F. donanaensis in one M. leprosa from Portil.

S. microcephalus was found in native and exotic turtles from the three localities, while F. donanaensis, was only observed in native and exotic turtles from Portil (Tables 1 and 2). An unidentified species of the genus Falcaustra was also found in addition to the larvae of a nematode from the genus Physaloptera found in one T. s. elegans (with 100 larvae in its intestinal tract) and in one $\mathrm{M}$. leprosa (Tables 1 and 2). Also a single female belonging to Aplectana sp. was found in one E. orbicularis from Doñana (Table 1).

Table 1

Prevalence of the helminth species found in the intestinal tracts of native turtles from southwestern of Spain

\begin{tabular}{lll} 
& \multicolumn{2}{l}{ Prevalence $(\%)$} \\
\cline { 2 - 3 } & Mauremys leprosa $(\mathrm{n}=7)$ & Emys orbicularis $(\mathrm{n}=3)$ \\
\hline Serpinema microcephalus & $85.7^{1,3}$ & $66.7^{1}$ \\
Falcaustra donanaensis & $14.31^{1}$ & - \\
Falcaustra sp. & $14.3^{2}$ & - \\
Physaloptera sp. & $14.3^{3}$ & - \\
Aplectana sp. & - & $33.3^{1}$ \\
\hline
\end{tabular}

\footnotetext{
1 Doñana Biological Reserve.

2 Acebuche Lagoon.

3 Portil Lagoon.
}

\section{Table 2}

Infection parameters of the helminths parasitizing Trachemys scripta elegans of Acebuche Lagoon and Portil Lagoon

\begin{tabular}{|c|c|c|c|c|c|}
\hline & \multirow{2}{*}{$\begin{array}{l}\text { Prevalence } \\
\text { (\%) }\end{array}$} & \multicolumn{2}{|c|}{ Intensity } & \multicolumn{2}{|c|}{ Abundance } \\
\hline & & Range & Mean \pm SD & $\mathrm{N}$ & Mean \pm SD \\
\hline \multicolumn{6}{|l|}{ Acebuche Lagoon } \\
\hline Serpinema microcephalus & 55.6 & $1-21$ & $2.8 \pm 5.1$ & 42 & $1.6 \pm 4.0$ \\
\hline Physaloptera sp. & 3.7 & - & - & 100 & - \\
\hline \multicolumn{6}{|l|}{ Portil Lagoon } \\
\hline Serpinema microcephalus & 93.8 & $1-75$ & $17.8 \pm 16.5$ & 533 & $16.7 \pm 16.5$ \\
\hline Falcaustra donanaensis & 12.5 & $1-6$ & $3.0 \pm 2.4$ & 12 & $0.4 \pm 1.3$ \\
\hline Falcaustra sp. & 2.7 & - & - & 17 & - \\
\hline
\end{tabular}

$\mathrm{N}=$ Total number of helminths (absolute abundance).
3.1. Helminth communities of the red-eared slider turtle Trachemys scripta elegans

The overall prevalence of infection of $\mathrm{T}$. s. elegans was significantly higher $(\mathrm{P}<0.0001)$ in Portil $(93.8 \%, 30 / 32)$ than in Acebuche (59.3\%, 16/27).

For each nematode species, prevalence, intensity of infection and abundance in each locality are shown in Table 2 . The helminth community of T.s. elegans was composed of three species in Portil, whereas only two species appeared in Acebuche, being only S. microcephalus common to both localities (Table 2).

All parasitized turtles from Portil were infected by S. microcephalus, at a lower prevalence than in Acebuche (Table 2). The other three species identified in this study had low prevalences $(<13 \%)$ (Table 2). Mean intensity and mean abundance of S. microcephalus in T. s. elegans were significantly higher in Portil than in Acebuche (Table 2) (intensity: $\mathrm{P}=0.003$; Abundance: $\mathrm{P}<0.0001$ ). Species richness differed significantly in both localities $(\mathrm{P}<0.0001)$, averaging 0.5 helminth species per turtle $(\mathrm{SD}=0.5, \min =0, \max =1)$ in Acebuche and $1.1(\mathrm{SD}=0.5, \min =0, \max =2)$ in Portil. Helminth abundance was higher in Portil $(\mathrm{P}<0.0001)$, with an average of 17.6 helminths per turtle ( $\mathrm{SD}=16.7, \min =0$, $\max =75$ ), whereas in Acebuche was of $5.3(\mathrm{SD}=19.3, \min =0$, $\max =100)$. A parasite diversity of $0.58(\mathrm{SD}=0.96)$ was found in Acebuche and of 0.23 $(\mathrm{SD}=0.04)$ in Portil.

\section{Discussion}

Helminth fauna has been studied previously for M. leprosa and E. orbicularis (López-Neyra, 1947; Lopez-Román, 1974; Lluch et al., 1987; Cordero del Campillo et al., 1994; Roca et al., 2005; Hidalgo-Vila et al., 2006) in other localities of Spain, with other Class of helminths (trematodes, cestodes or acanthocephalan) described.

Only five species of nematodes were identified in our study in native and exotic turtles, all of them common to the Palearctic Region. This low number of helminth species is characteristic of other populations of these turtles. Thus, five helminth species composed the community of M. leprosa in Extremadura (Roca et al., 2005) being nematodes S. microcephalus and Falcaustra sp. the most prevalent species recorded in this locality. The helminth fauna of E. orbicularis has been described in turtles from Central Europe, where eight helminth species were identified (Kirin, 2001). In northwestern Spain, two additional helminth species were reported in E. orbicularis (Segade et al., 2006). In contrast, at present there are not published data about the helminth communities of free-living exotic turtles T. s. elegans in their recent introduced areas.

In its original area, 17 helminth species were reported for $\mathrm{T}$. s. elegans, being Serpinema trispinosum and Neoechinorrhynchus the most prevalent species (Rosen and Marquardt, 1978; Moravec and Vargas-Vázquez, 1998). None of the parasites reported for these areas were found in T. s. elegans from southwestern Spain, where turtles are infected by helminth fauna of native species, reaching similar or higher prevalence.

This could be due to most of the exotic traded turtles T. s. elegans proceed from egg incubation in farms and have not been in contact with natural habitats (Warwick et al., 2001). However colonization of exotic hosts by local helminths has been previously described in introduced Mediterranean geckos (Criscione and Font, 2001).

F. donanaensis has been detected in this study in native and in exotic turtles coexisting in Portil. Previously detection of the same species in M. leprosa from Doñana (Hidalgo-Vila et al., 2006), an area in which exotic turtles are not present, reveals that the presence of these nematodes in exotic turtles has resulted from the cross transmission of $\mathrm{F}$. donanaensis from native turtles. 
S. microcephalus is a common helminth of turtles in the Palearctic Region (Baker, 1979), and has been previously cited in M. leprosa (López-Neyra, 1947; Lluch et al., 1987; Cordero del Campillo et al., 1994; Roca et al., 2005), and E. orbicularis (Baker, 1979; Kirin, 2001). However, this is also the first report of cross transmission of S. microcephalus from the native turtles to the exotic ones (T. s. elegans) commonly parasitized by S. trispinosum (Leidy, 1852) in its native range of distribution, Nearctic Region (Baker, 1979; Rosen and Marquardt, 1978).

Differences in prevalence and abundance of S. microcephalus in exotic turtles between sites may reflect differences in the diet of turtles. Adults of T. s. elegans and other Emydid species are mainly herbivorous (Moll and Legler, 1971; Parmenter and Avery, 1990; Esch et al., 1993; Dreslik, 1999) and herbivorism favours infection by species with indirect life cycles due to accidental ingestion of intermediate or paratenic hosts, as copepods or other crustaceans. $\mathrm{S}$. microcephalus is associated with the vegetation on which the turtles feed (Esch et al., 1993). Thus, the higher prevalence, abundance and intensity of infection of turtles from Portil may be related to the higher frequency of plant matter in the diet of these turtles than in those from Acebuche (N. Perez-Santigosa, unpublished $\mathrm{PhD}$.). Infection intensities could be also related with the abundance of intermediate hosts in each locality as has been previously described (Esch and Gibbons, 1979a; Esch et al., 1979b).

Other parasites of genus Falcaustra were found in the three localities. Although females of this species were different to $F$. donanaensis females, the absence of males made impossible its identification.

Nematodes belonging to genus Physaloptera are indirect life cycle species with insects as intermediate host (Anderson, 2000). Infection rates in wild reptiles are often high and infections may be massive (Telford, 1971) as those recorded in one T. s. elegans of this study. Physaloptera abbreviata has been identified in Lacerta lepida and Podarcis hispanica from the Iberian Peninsula (Lluch et al., 1987), however this is the first report of genus Physaloptera in turtles in the Palearctic Region.

Finding one individual of Aplectana sp. in one E. orbicularis could be accidental. The four species of genus Aplectana described in the Iberian Peninsula are parasites of amphibians (Rana perezi, Bufo bufo and Bufo calamita) (Lluch et al., 1987). Because these amphibian species are present in the study area (Díaz-Paniagua et al., 2005) it is possible that the parasite was ingested during predation.

In conclusion, the introduction and establishment of exotic turtles does not seem to have been accompanied by a similar introduction of exotic parasites. However, the increasing popularity of different species of turtles as pets proceeding from different countries of the world increases the risk of introduction of parasites. Therefore controls and regulations are recommended to prevent additional threatens to native fauna.

\section{Acknowledgements}

We thank X. Ruiz A. Portheault and A. Conejo for their field and laboratory assistance and to K. Acevedo-Whitehouse for her language revision to the manuscript. J. Hidalgo-Vila was financed by an I3P-CSIC research grant. This study was supported by Consejeria Medio ambiente-Junta de Andalucia (UE co-funded project and RNM 128).

\section{References}

Anderson, R.C., 2000. Nematode Parasites of Vertebrates: their Development and Transmission, second ed. CABI Publishing, Wallingford, Oxon, UK.

Baker, M.R., 1979. Serpinema spp. (Nematoda: Camallanidae) from turtles of North America and Europe. Canadian Journal of Zoology 57, 934-939.
Baker, M.R., 1980. Revision of old world species of the genus Aplectana Railliet and Henry, 1916 (Nematoda: Cosmocercidae). Bulletin du Museum National d'Historie Naturelle, Paris. Ser 4 Sect A2, pp. 955-998.

Bush, A.O., Lafferty, K.D., Lotz, J.M., Shostak, A.W., 1997. Parasitology meets ecology on its own terms: Margolis et al revisited. Journal of Parasitology 83, 575-583.

Cadi, A., Joly, P., 2003. Competition for basking places between the endangered European pond turtle (Emys orbicularis galloitalica) and the introduced slider turtle (Trachemys scripta elegans). Canadian Journal of Zoology 81, 1392-1398.

Cadi, A., Joly, P., 2004. Impact of the introduction of the slider turtle (Trachemys scripta elegans) on survival rates of European pond turtle (Emys orbicularis). Biodiversity and Conservation 13, 2511-2518.

Cordero del Campillo, M., Castañón-Ordoñez, L., Reguera-Feo, A., 1994. Índice Catálogo de Zooparásitos Ibéricos, Segunda edición. Secretariado de Publicaciones, Universidad de León, León, Spain.

Cox, N., Chanson, J., Stuart, S., (compilers), 2006. The Status and Distribution of Reptiles and Amphibians of the Mediterranean Basin. IUCN, Gland, Switzerland and Cambridge, UK.

Criscione, C.D., Font, W.F., 2001. The guest playing host: colonization of the introduced Mediterranean gecko, Hemidactylus turcicus, by helminth parasites in Southeastern Louisiana. Journal of Parasitology 87, 1273-1278.

Díaz-Paniagua, C., Gómez Rodríguez, C., Portheault, A., de Vries W.W., 2005. Los anfibios de Doñana. Naturaleza y Parques Nacionales. Serie Técnica. Ministerio Medio Ambiente. Organismo Autónomo Parques Naturales, Madrid, Spain.

Dreslik, M.J., 1999. Dietary notes on the red-eared slider (Trachemys scripta) and river cooter (Pseudemys concinna) from southern Illinois. Transactions of the Illinois State Academy of Science 92, 233-241.

Esch, G.W., Gibbons, J.W., 1979a. The distribution and abundance of enteric helminths in Chrysemys s. scripta from various habitats on the Savannah River Plant in South Carolina. Journal of Parasitology 65, 624-632.

Esch, G.W., Gibbons, J.W., Bourque, J.E., 1979b. Species diversity of helminth parasites in Chrysemys scripta from a variety of habitats in South Carolina. Journal of Parasitology 65, 633-638.

Esch, G.W., Marcogliese, D.J., Goater, T.M., Jacobson, K.C., 1993. Aspects of the evolution and ecology of helminth parasites in turtles: a review. In: Gibbons, J.W. (Ed.), Life History and Ecology of the Slider Turtle. Smithsonian Institution Press, Washington DC, pp. 299-307.

Hidalgo-Vila, J., Ribas, A., Florencio, M., Pérez-Santigosa, N., Casanova, J.C., 2006. Falcaustra donanaensis sp. nov. (Nematoda: Kathlaniidae) a parasite of Mauremy leprosa (Testudines, Bataguridae) in Spain. Parasitology Research 99, 410-413.

Kirin, D.A., 2001. New data on the helminth fauna of Emys orbicularis L (1758) Reptilia, Emydidae) in South Bulgaria. Comptes rendus de l'Académie bulgare des Sciences 54, 95-98.

López-Neyra, C.R., 1947. Helmintos de los vertebrados Ibéricos. C.S.I.C. Patronato "Santiago Ramón y Cajal”. Granada, Spain.

Lopez-Román, R., 1974. Trematodos de las tortugas de España, I. Redescripción de Telorchis solivagus Odhner, 1902 (Telorchidae digenea) parásito de Clemys leprosa (Schweigger). Revista Iberica de Parasitología 34, 185-195.

Lluch, J., Roca, V., Navarro, P., Mas-Coma, S., 1987. Helmintofauna de los herpetos ibéricos: Estado actual de conocimientos, consideraciones ecológicas y estimaciones corológicas. In: Sans-Coma, V., Mas-Coma, S., Gosálbez, J. (Eds.), Mamíferos y Helmintos, Ketres Editora. Barcelona, pp. 143-161.

Magurran, A.E., 2004. Measuring Biological Diversity. Blackwell Publishing, Oxford, UK.

Moll, E.O., Legler, J.M., 1971. The life history of a neotropical slider turtle, Pseudemys scripta (Schoepff), in Panama. Bulletin of the Los Angeles County Museum of Natural History Science 11, 1-102.

Moravec, F., Vargas-Vázquez, J., 1998. Some endohelminths from the freshwater turtle Trachemys scripta from Yucatan, Mexico. Journal of Natural History 32, 455-468.

Parmenter, R.R., Avery, H.W., 1990. The feeding ecology of the slider turtle. In: Gibbons, J.W. (Ed.), Life History and Ecology of the Slider Turtle. Smithsonian Institution Press, Washington DC, pp. 257-266.

Pleguezuelos, J.M., 2002. Las especies introducidas de anfibios y reptiles. In: Pleguezuelos, J.M., Márquez, R., Lizana, M. (Eds.), Atlas y Libro Rojo de los anfibios y reptiles de España. Dirección General de Conservación de la Naturaleza-Asociación Herpetológica Española, Madrid, pp. 501-532.

Roca, V., Sánchez-Torres, N., Martín, J.E., 2005. Intestinal helminths parasitizing Mauremys leprosa (Chelonia: Bataguridae) from Extremadura (western Spain). Revista Española de Herpetología 19, 47-55.

Rosen, R., Marquardt, W.C., 1978. Helminth parasites of the red-Eared turtle (Pseudemys scripta elegans) in Central Arkansas. Journal of Parasitology 64, 1148-1149.

Salzberg, A., 1995. Report on import/export turtle trade in the United States. In: Proceedings of the International Congress of Chelonian Conservation, pp. 314322.

Segade, P., Crespo, C., Ayres, C., Cordero, A., Arias, M.C., García-Estévez, J.M., Iglesias Blanco, R., 2006. Eimeria species from the European pond turtle, Emys orbicularis (Reptilia: Testudines), in Galicia (NW Spain), with description of two new species. Journal of Parasitology 92, 69-72.

Telford, S.R., 1971. Parasitic diseases of reptiles. Journal of the American Veterinary Medical Association 159, 1644-1652.

Telecky, T.M., 2001. United States import and export of live turtles and tortoises. Turtle and Tortoise Newsletter 4, 8-13.

Warwick, C., Lambiris, A.J.L., Westwood, D., Steedman, C., 2001. Reptile-related salmonellosis. Journal of the Royal Society of Medicine 94, 124-126. 